\title{
MEWUJUDKAN PERKEMBANGAN MUTU PENDIDIKAN DI ERA REVOLUSI 4.0 DENGAN SUPERVISI PENDIDIKAN
}

\author{
NELLA DWI PUTRI
}

17029069

np55017@gmail.com

\begin{abstract}
ABSTRAK
Pendidikan di Indonesia masih belum memenuhi perkembangan mutu pendidikan yang diharapkan. Jika dibandingkan dengan kualitas pendidikan terbaik di dunia, Indonesia bisa dikategorikn jauh tertinggal. Hal ini dapat dilihat dari prestasi peserta didik yang menjadi tolak ukur mutu pendidikan. Dalam meningkatkan mutu pendidikan, supervisi pendidikan memiliki peran yang sangat penting dan sangat dibutuhkan dalam pengembangan mutu pendidikan.
\end{abstract}

Kata kunci : supervisi, mutu, pendidikan

\section{LATAR BELAKANG}

Menurut yang dikemukakan oleh Sutrisno Rahmad (Rahmat 2015) Interaksi antara peserta didik dengan pendidik dan sumber-sumber pendidikan tersebut dapat berlangsung dalam situasi pendidikan, pengajaran, latihan serta bimbingan. Situasi pendidikan, pengajaran, latihan serta bimbingan yang baik antara pendidik dan peserta didik akan mendorong tercapainya tujuan pendidikan. Dengan tercapainya tujua pendidikan maka akan berdampak pada mutu pendidikan suatu Negara. Dan perkembangan mutu pendidikan dapat dilihat dari dunia pendidikan 
khususnya bidang pengajaran tolak ukur keberhasilan pendidikan diantaranya ditentukan oleh faktor pendidik yang dapat ditinjau dari supervisi pendidikan.

Supervisi pendidikan sering juga disebut sebagai pengawasan pendidikan, dimana supervisi pendidikan pasti akan mengalami perkembangan sesuai dengan perkembangan zaman. Menurut Giri (Giri n.d.) bila pada masa lalu pengertian supervise lebih ditekankan pada pemberian-pemberian berorientasi pada benar salah sebuah pekerjaan dengan cara yang tidak jarang, menakutkan, memberikan sanksi dan menjerumuskan, maka pada saat ini supervisi lebih ditekankan pada kegiatan pembinaan dan pengembangan pada orang yang disuvervisi. Untuk mewujudkan perkembangan mutu pendidikan terlebi dahulu kita harus mengetahui apakah konsep supervisi pendidikan dan bagaimana peran guru sebagai penunjang mutu pendidikan. Tujuannya agar kita mengetahui berbagai hal mengenai supervisi pendidikan dan peran guru dalam proses pembelajaran.

\section{PEMBAHASAN}

Pada era Revolusi 4.0 dimana terjadinya kemajuan di bidang teknologi dan tidak menutup kemungkinan semua pekerjaan manusia akan digantikan oleh mesin. Kemajuan dalam berbagai bidang atau kemajuan dalam bidang ilmu pengetahuan dan teknologi ini dilatarbelakangi oleh kemajuan pendidikan. Mengikuti perkembangan zaman, kita dituntut untuk berfikir, menciptakan, dan melakukan perubahan dengan dibekali ilmu pengetahuan. Semua ilmu pengetahuan dapat diperoleh dari proses pembelajaran. Pembelajaran yang efektif dan efisien dapat menghasilkan output peserta didik yang berkualitas. Pembelajaran yang kondusif dan dinamis juga merupakan faktor terwujudnya mutu pendidikan. Menurut yang dikemukakan oleh ahmad sabandi (Sabandi 2013) perkembangan supervise pendidikan berkembang seiring dengan perkembangan ilmu pengetahuan, teknologi, serta sosial ekonomi dan budaya masyarakat. Supervisi bergerak dari berbentuk inspeksi dimana otoritas lebih didominasi oleh supervisor dan guru bersama.

Keberadaan supervisi pendidikan di dalam pendidikan memiliki peran penting dalam mengawasi , mengamati, dan mengarahkan kinerja guru dalam membimbing anak didik menjadi berprestasi dan menciptakan generasi yang berkualitas. Perkembangan mutu pendidikan akan berhasil dengan baik jika didukung oleh supervisi yang baik juga, serta peran serta pendidik 
dalam proses pendidikan. Karena dalam dunia pendidikan khususnya bidang pengajaran tolak ukur keberhasilannya diantaranya ditentukan oleh faktor guru. Sekolah sebagai tempat transfer ilmu dari guru ke murid dapat meningkatkan mutu pendidikannya dan mengetahui perkembangan mutu pendidikan melalui supervisi, selain itu supervisi juga sangat dibutuhkan oleh seorang guru yang mengalami berbagai hambatan. Oleh karena itu supervisi sangat penting dan sangat dibutuhkan untuk pengembangan mutu pendidikan.

\section{KESIMPULAN DAN SARAN}

Supervisi pendidikan merupakan hal yang sangat penting dalam pengembangan mutu pendidikan. Dimana kegiatan supervise mencakup kegiatan pengawasan terhadap pelaksaaan proses pendidikan. Dan juga mutu pendidikan dapat tercapai dengan efektif dapat dilihat dari peran guru dalam pengajaran. Dalam proses belajar mengajar pendidiklah nantinya yang akan menghasilkan peserta didik yang berprestasi dan berkarakter baik. Di era revolusi industry 4.0 ini diharapkan kita harus lebih meningkatkan mutu pendidikan untuk bisa berprestasi dan berkontribusi agar kita tidak tertinggal dari perkembangan zaman.

\section{REFERENSI}

Giri, i made ariasa. "Supervisi Pendidikan Dalam Pningkatan Mutu Pendidikan Di Sekolah." jurnal penjaminan mutu: 1-53. https://www.academia.edu/30510048/SUPERVISI_PENDIDIKAN_DALAM_PENINGKA TAN_MUTU_PENDIDIKAN_DI_SEKOLAH.

Rahmat, Sutrisno. 2015. "Supervisi Pendidikan Guru Profesional.” http://stitmatuban.ac.id/wpcontent/uploads/2015/10/TD1.3-Supervisi-Pendidikan-H.-Sutrisno-Rahmat.pdf.

Sabandi, Ahmad. 2013. "Supervisi Pendidikan Untuk Pengembangan Profesionalitas Guru Berkelanjutan.” pedagogik, jurnal ilmiah ilmu pendidikan XIII(2): 1-13. http://ejournal.unp.ac.id/index.php/pedagogi/article/view/4275. 